\title{
KRITIK MODERNITAS MENUJU PENCERAHAN: PERSPEKTIF TEORI KRITIS MAZHAB FRANKFURT
}

\author{
Luthfiyah \\ Institut Agama Islam (IAI) Muhammadiyah Bima \\ ruslanamarizqi@gmail.com
}

\begin{abstract}
Abstrak
Sebagai teori kritis, Mazhab Frankfurt bermaksud untuk menciptakan kesadaran kritis masyarakat dengan menyoroti segala gejala dalam hubungan individu dan masyarakat mencakup bidang ekonomi, politik, hukum, agama, seni, social kemasyarakatan dan ilmu pengetahuan. Ini berarti, teori kritis pada hakekatnya hendak menjadi Aufklarung atau Pencerahan. Aufklarung berarti mau membuat cerah, mau menyingkap segala tabir yang menutup kenyataan yang tak manusiawi terhadap kesadaran kita. Teori kritis dalam hubungan ini berbicara tentang selubung menyeluruh yang membutakan kita terhadap kenyataan yang sebenarnya. Semua segi kehidupan masyarakat menimbulkan kesan bahwa semuanya baik adanya. Semua kebutuhan dapat dipuaskan, semuanya efisien, produktif, lancar, dan bermanfaat. Semua kesan semu itu harus dibuka. Sehingga muncullah istilah "totalitas yang ingin di buka".
\end{abstract}

Kata Kunci: Mazhab Frankfurt, Teori Kritis, Aufklarung/Pencerahan

\section{Pendahuluan}

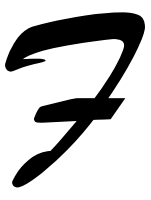

ilsafat abad ke 20 secara garis besar telah diwarnai oleh empat aliran besar, yaitu: Fenomenologi dan Eksistensialisme, Neo-Thomisme, filsafat Analitis dan aliran-aliran Neo-Marxisme. Dalam hal ini teori kritis termasuk aliran terakhir yang meskipun oleh kaum Marxis tidak dianggap Marxis lagi. NeoMarxisme sendiri sebetulnya terdiri dari segala macam aliran dan filsafat. Ciri yang khas bagi Neo-Marxisme yang lebih tepat disebut sebagai filsafat Marxis saja adalah bahwa mereka semua menolak penyempitan ajaran Karl Marx oleh Friedrich Engels. Engels, sebagai kawan akrab dan setia Marx merumuskan ajaran-ajaran kawannya dalam bentuk sebuah sistem yang jelas, sederhana, dan logis. Ajaran inilah yang kemudian menjadi "Marxisme resmi". 1

Marxisme gubahan Engels itu kemudian dianut oleh Lenin dan bersama ajaran Engels dan Lenin menjadi ideologi Komunisme internasional dengan nama MarxismeLeninisme. Aliran-aliran Marxis yang muncul kemudian dan pada hakekatnya terbatas pada lingkungan akademik, semua menolak Marxisme-Leninisme. Aliran ini disebut Neo-Marxisme, karena ia baru muncul pada abad ini. Mereka berpendapat bahwa Engels sudah menghilangkan dimensi dalektis dari ajaran Marx.

Untuk itu, ada di antara mereka yang mau mengembalikan harkat Marxisme yang sebenarnya, dengan mencari kembali apa inti darinya. Mereka antara lain: Georg Lukaos

\footnotetext{
${ }^{1}$ Frans Magnes Suseno, Filsafat Sebagai Ilmu Kritis, (Yogyakarta: Kanisius, 1992), 159-60.
} 
dan Karl Korsch. Ada yang atas dasar dialektika Marx mengembangkan tema manusia seperti Ernst Bloch. Ada pula filsafat-filsafat yang menginterpretasikan Marx secara eksistensialistik, seperti Leszek Kolakowski dan Adam Schaff di Polandia. Namun pada akhirnya mereka dibungkamkan dan Kolakowski pindah ke Barat. Sementara kelompok filosof Kroasia yang menerbitkan "majalah praktis" pada permulaan tahun 70-an dilarang dan mereka sendiri dipecat dari Universitas oleh pemerintahan Tito.

Aliran Neo-Marxis yang terpenting tentulah mazhab Frankfurt. Mazhab ini memakai istilah Neo-Marxisme, karena paham ini menolak setiap bentuk dogmatisasi Karl Marx, meskipun memang sangat diilhami oleh Hegel dan Marx sendiri. Bertentangan dengan kaum Marxis "bebas", para pemikir ini tidak mau disebut kaum Marxis dan bahkan mereka sering tidak dapat menerima pemberian nama "Kaum NeoMarxis".2

Meskipun demikian, penggunaan istilah tersebut dapat dipertanggung jawabkan, karena bertentangan dengan kebanyakan aliran filsafat dalam abad 20. Mereka sungguhsungguh menerima permasalahan yang dibahas Marx serta metode yang dipakainya. Dalam hal ini mereka berdiri segaris dengan Sartre (dalam usia yang lebih tua), dan mereka masih dapat dipersamakan dengan sejumlah penganut personalisme, seperti Mounier.

Terlepas dari itu semua, satu hal yang menjadi ciri khas sekaligus misi utama teori kritis adalah ingin menjadikan teori tidak sebagai teori per se, namun juga mesti memiliki implikasi praktis terhadap masyarakat. Artinya dalam teori kritis ada penekanan hubungan antara teori dan praksis, dan teori mesti dapat diterjemahkan ke dalam tindakan (praksis). Ini pula masalahnya yang melandasi pemikiran teori kritis tentang ilmuan (sosial); di mana dalam pandangan teori kritis posisi ilmuan (sosial) bukan cuma bertugas memberikan pengetahuan perihal fenomena social atau menjelaskan kondisi social semata, melainkan juga mesti memberikan penerangan atau pencerahan kepada para pelaku social ihwal kondisi social yang menindas mereka. Sehingga dengan menyadari kondisi dan situasi social tersebut masyarakat dapat memahami dan mengubah kondisi yang sebetulnya memanipulasi dan menindas mereka itu. ${ }^{3}$

Dengan demikian teori kritis tidak hanya sekedar hendak berada pada tataran pengetahuan akan tetapi juga menyentuh pada ranah tindakan. Sehingga kritis di sini dimaksudkan untuk mengkritisi segala hal yang membelenggu masyarakat dari segala sisi kehidupan, baik yang berkaitan dengan teori maupun yang langsung berkenaan dengan praktik-praktik kehidupan itu sendiri.

\footnotetext{
${ }^{2}$ Bernard Delfgaauw, Filsafat Abad 20 (Yogyakarta: Tiara Wacana, 1988), 163.

${ }^{3}$ Dr. Akhyar Yusuf Lubis, Pemikiran Kritis Kontemporer; dari Teori Kritis, Culture Studies, Feminism, Post-Kolonial hingga Multikulturalisme, (Jakarta: Rajawali Press, 2016), 13.
} 


\section{Teori Kritis Mazhab Frankfurt}

Teori kritis adalah anak dari aliran besar filsafat yang terinspirasi dari Marx, namun ironisnya justru akhirnya menjadi yang paling jauh meninggalkan Marx. ${ }^{4}$ Pengertian kritis di sini dimaksudkan sebagai aliran yang kritis terhadap ajaran-ajaran di bidang social dan juga kritis terhadap keadaan masyarakat saat itu, di mana sangat memerlukan perubahan secara radikal. Kata "kritik" adalah konsep kunci untuk memahami teori kritis. Kritis juga merupakan suatu program bagi mazhab Frankfurt untuk merumuskan suatu teori yang bersifat emansipatoris tentang kebudayaan dan masyarakat modern.

Kritik-kritik mereka diarahkan ke berbagai kehidupan masyarakat modern, seperti seni, ilmu pengetahuan, ekonomi, politik dan kebudayaan pada umumnya, yang bagi mereka telah menjadi rancu karena diselubungi oleh ideologi-ideologi yang menguntungkan pihak-pihak tertentu dan sekaligus mengasingkan manusia individual dari masyarakatnya. ${ }^{5}$ Bagi mereka sendiri, kata kritik ini tidak lain berakar pada tradisi filsafat itu sendiri.

Teori kritis merupakan aliran filsafat yang dipraktekkan dalam Mazhab Frankfurt yang digunakan untuk menunjukkan sekelompok sarjana yang bekerja pada sebuah lembaga penelitian social di Frankfurt, Jerman. Lembaga ini didirikan pada tahun 1923 oleh Felix Weil, anak seorang pedagang gandum yang kaya raya, sehingga lembaga ini menjadi lembaga yang independen dan mempunyai dasar finansial sendiri untuk menyelidiki persoalan-persoalan social. ${ }^{6}$

Lembaga penelitian social Frankfurt (Die Frankfurter Schule) mencapai suatu periode keemasan ketika Marx Horkheimer menjadi direkturnya pada tahun 1930. Sejak permulaannya, lembaga penelitian di Frankfurt ini berupaya untuk mengumpulkan sarjana-sarjana dari berbagai bidang keahlian. Dengan tujuan supaya persoalan-persoalan yang menyangkut masyarakat dapat dipelajari dari berbagai bidang ilmiah. Pada masa kepemimpinannya, Marx Horkheimer sangat mementingkan kerja sama antara para anggota lembaga penelitian tersebut, sehingga banyak artikel dalam majalahnya dapat dipandang sebagai buah hasil diskusi bersama.

Dalam perkembangannya lembaga penelitian ini ditutup atas perintah pemerintah nasioanal sosialis ketika Hitler berkuasa pada tahun 1933, karena HorKheimer dan kawan-kawannya mengkritik dan menentang aliran politik ini. Kondisi politik di Jerman

\footnotetext{
${ }^{4}$ Beberapa ajaran dan asumsi pandangan atau pemikiran Marx yang ditinggalkan oleh teori kritis antara lain; materialism historis, kehancuran kapitalisme, teori nilai pekerjaan, analisis kelas serta teori tentang kaum proletas sebagai subjek evolusi. Elaborasi lebih lanjut baca dalam Akhyar Yusuf Lubis, Pemikiran Kritis Kontemporer, 9-12.

5 Sunarto, "Konstruksi Epistemologi Max Horkheimer: Kritik atas Masyarakat Modern"dalam Listiyono, Santoso dan Sunarto dkk., Epistemologi Kiri, (Yogyakarta: Ar-Ruz, 2003), 98.

${ }^{6}$ Pada saat itu lembaga penlitian ini tidak ditangani oleh penlitian ilmiah, seperti sejarah gerakan kaum buruh da nasal usul anti semitisme. Oleh karena itu lembaga ini tidak mau tergantung pada Universitas Frankfurt yang pada saat itu masih relative muda, walaupun beberapa anggotanya telah mengajar di Universitas tersebut.
} 
yang tidak kondusif bagi perkembanngan lembaga penelitian ini telah disinyalir sebelumnya oleh Horkheimer. Oleh karena itu, ia membuka cabang di beberapa Negara di luar Jerman, anatar lain: di London, Paris, Amerika dan Jenewa. Setelah dirasa kondisi politik semakin membaik (pada tahun 1949 dan 1950), Horkheimer, T. Aforno dan F. Pollock, kembali pulang ke Jerman. Kemudian lembaga penelitian ini kembali dibangun dan mulai berafiliasi dengan Universitas di Frankfurt. ${ }^{7}$ Dalam tahun 60 -an pemikiran lembaga penelitian mencapai puncak pengaruhnya dalam kalangan intelektual, khususnya para mahasiswa. Keadaan ini berlangsung sampai kira-kira tahun 1967, ketika Isozialistischer Deutscher Studentenbund (SDS) mulai menrima kekerasan sebagai cara beraksi. Maka ketika itu pula terjadi perpecahan antara aktifitas-aktifitas mahasiswa dan pemimpin mazhab Frankfurt.

Untuk lebih memberikan sebuah gambaran secara jelas mengenai perkembangan sejak munculnya aliran ini, setidaknya terdapat delapan tahapan perubahan dalam mazhab Frankfurt, yaitu: ${ }^{8}$ pertama, adalah studi-studi empiris-historis di zaman Carl Grunberg; kedua, tahap munculnya teori social-interdisipliner-materialis pada pertengahan 1930-an, ketika Institut ini dipimpin oleh Max Horkheimer; ketiga, fase munculnya teori kritik social selama Institut ini berada dalam pengungsian antara tahun 1937 hingga awal tahun 1940-an; keempat, adalah periode menyebarnya anggota Institut ini ke berbagai Negara selama tahun 1940-an, dan munculnya Theodor Adorno dan Max Horkheimer sebagai teoritikus utama.

Selanjutnya pada tahapan kelima, adalah masa di mana Institut ini kembali ke Jerman selama tahun 1950 dan 1960-an; tahap keenam, merupakan masa perumusan teori kritis oleh Fromm, Lowenthall, Marcuse dan tokoh-tokoh lainnya yang tetap bermukin di Amerika Serikat, yang ternyata berbeda dengan pemikiran teman-teman mereka yang berada di Jerman; ketujuh, adalah berlanjutnya proyek-proyek Institut ini dalam mengembangkan teori social oleh tokoh-tokoh baru, seperti Jurgen Habermas, Oskal Negt, Alfred Schmidt dan lain sebagainya pada tahun 1970 dan 1980-an; dan tahap kedelapan adalah munculnya teoritisi generasi baru yang aktif di dunia akademik Eropa dan Amerika Serikat.

Dari kedelapan tahapan di atas dapat dilihat bahwa Mazhab Frankfurt merupakan perkumpulam sekelompok intelektual "Marxian", yang mencoba untuk mengkritisi masalah-masalah social. Di mana langkah mereka bukan tanpa hambatan bahkan harus mengalami masa-masa sulit (dipengungsian). Akan tetapi dengan keteguhan dan kerja sama yang solid antar anggotanya, perkumpulan ini mampu melewati dan berkumpul kembali di Jerman, tempat negara kelahirannya. Dan dalam perkembangannya kemudian

\footnotetext{
${ }^{7}$ K. Bertens, Filsafat Barat abad XX: Ingris-Jerman, (Jakarta: Gramedia, 1983), 177.

${ }^{8}$ Douglas Kellner, "Frankfurt School (Aliran Frankfurt)", dalam Adam Kuper dan Jessica Kuper (ed.), Ensiklopedi Ilmu-ilmu Sosial, terj. Haris Munandar (et.al), (Jakarta: Raja Grafindo Persada, 2000), 376.
} 
pemikiran Mazhab Frankfurt dapat berpengaruh bahkan sampai ke Negara-negara lain termasuk benua Amerika dan Asia.

Selanjutnya dalam konteks filsafat, Mazhab Frankfurt memiliki pokok pikiran sebagai berikut: ${ }^{9}$

1. Objek analisis adalah masyarakat masa kini, bukan masyarakat ketika Karl Marx masih hidup.

2. Filsafat bukan hanya kontemplasi, suatu perenungan mendalam dan radikal yang jauh dari realitas, atau tidak membumi.

3. Filsafat seharusnya dapat merubah masyarakat, suatu upaya emansipasi dari belenggu yang muncul sebagai akibat dari pekerjaannya.

4. Aufklarung menyingkap tabir kegelapan, upaya memberi pencerahan pada manusia modern akan kemajuan semu masyarakat industri yang dehumanisasi.

5. Menolak perubahan dengan cara yang revolusioner, karena hal itu justru akan memunculkan dehumanisasi.

Dari lima pokok pikiran di atas menunjukkan bahwa Mazhab Frankfurt memiliki orientasi yang bersifat progressif, maju dan kekinian. Karena meskipun mereka adalah "Marxian", tetapi objek analisisnya tidak semata-mata pada masalah social yang telah lampau di masa Karl Marx. Maka dengan memaknai filsafat bukan hanya sebagai sesuatu yang teoritis dan hampa, Mazhab Frankfurt justru menghendaki agar filsafat bersifat emansipatoris agar dapat dirasakan manfaatnya oleh masayarakat secara praktis.

Selain itu ajaran Mazhab Frankfurt merupakan instrument menuju pencerahan, karena seperti disinyalir oleh Adorno ${ }^{10}$ bahwa manusia ingin membebaskan diri dengan menguasai alam. Tetapi yang terjadi justru sebaliknya. Di mana manusia telah dikuasai oleh alam. Inilah salah satu kenyataan yang menunjukkan bahwa telah terjadi dehumanisasi oleh karena perbuatan manusia itu sendiri yang telah mereduksi kebebasan manusia. Pada akhirnya manusia justru terbelenggu dan menjadi dilema.

Realitas dehumanisasi dan denaturalisasi tersebut disebabkan oleh struktur masyarakat dan pengetahuan yang terlalu mengadopsi perkembangan ilmu-ilmu alam dan

\footnotetext{
${ }^{9}$ George Friedman, The Political Philosophy of Frankfurt School (London: Cornel Univercity Press, 1981).

${ }^{10}$ Dalam perkembangannya, Mazhab Frankfurt telah melahirkan banyak pemikir-pemikir lintas generasi disamping tokoh-tokoh teori kritis yang sangat berpengaruh. Adapun pemikir-pemikir dalam Mazhab Frankrurt dapat dikelompokkan menjadi tiga generasi, yaitu: generasi pertama yang dipelopori oleh Theodor W. Adorno, Walter Benjamin, Max Horkheimer Erich Fromm, dan Herbert Marcuse; generasi kedua dengan tokoh utamanya Jurgen Habermas, Albrech Welmer, Oskar Negt, Claus Offed an Karl Otto Apel; dan generasi ketiga ditokohi oleh Axel Honneth. Meskipun mereka berada dalam satu mazhab dalam teori kritis, akan tetapi tidak menutup kemungkinan bagi mereka untuk bersikap kritis pada teman sesama pemikir dalam Mazhab Frankfurt. Bahkan tak jarang bagi mereka untuk saling mengkritik antar sekawan dalam satu generasi atau juga pemikiran para pendahulunya. Mengingat mereka berasal dari latar belakang disiplin keilmuan yang beragam, maka sangat terbuka kemungkinan untuk menghasilkan kajian yang juga bersifat lintas-disipliner (interdisipliner dan bahkan multidisipliner) dan pemikiran yang variatif. Baca Akhyar Yusuf Lubis, Pemikiran Kritis Kontemporer, 4-5.
} 
industri mutakhir. Akibat lainnya ialah manusia diasingkan dari dirinya sendiri dan kebingungan menghadapi kenyataan yang sebenarnya direkayasa sendiri. Definisi alienasi ini diartikan berbeda dari istilah Marx, yaitu bukan terfokus pada unsur ekonomi melainkan lebih dilihat dari perspektif sosio kultural dan psikologi.

\section{Argumen Dialektika Pencerahan Teori Kritis}

Sebagai teori kritis, maka teori yang dikembangkan oleh Hoekheimer dan Adorno bermaksud untuk menciptakan kesadaran kritis. Ini berarti, teori kritis pada hakekatnya hendak menjadi Aufklarung atau Pencerahan. Aufklarung berarti mau membuat cerah, mau menyingkap segala tabir yang menutup kenyataan yang tak manusiawi terhadap kesadaran kita. Teori kritis dalam hubungan ini berbicara tentang "verblendungeszusammenhang" (kaitan ketersilauan). ${ }^{11}$ Yaitu semacam selubung menyeluruh yang membutakan kita terhadap kenyataan yang sebenarnya.

Selanjutnya Frans Magnes Suseno menegaskan bahwa dalam masyarakat industri maju, kontradisksi-kontradiksi, frustasi-frustasi, penindasan-penindasan tidak lagi tampak. Semua segi kehidupan masyarakat menimbulkan kesan bahwa semuanya baik adanya. Semua kebutuhan dapat dipuaskan, semuanya efisien, produktif, lancar, dan bermanfaat. Semua kesan semu itu harus dibuka. Sehingga muncullah istilah "totalitas yang ingin di buka". ${ }^{12}$

Teori kritis hendak memberikan sesuatu yang lain, yang bukan berupa pencerminan tidak memihak kepada masyarakat. Dalam hal ini yang terpenting ialah menimbulkan kesadaran bahwa suatu filsafat masyarakat tanpa penyelidikan empirik hanya akan menghasilkan kerangka pemikiran yang hampa, yang tidak memberikan keinsyafan apapun mengenai struktur masyarakat yang ada. Tetapi sebaliknya, penyelidikan empiris akan merupakan kegiatan yang sia-sia, apabila tidak disertai dengan kerangka kefilsafatan yang mewadahi serta memberi makna kepada penyelidikan tersebut.

Dengan demikian tugas teori kritis yang pertama adalah menyadarkan para penyelidik bahwa penyelidikan terikat masyarakat pada dua hal, yaitu: mendapatkan kerangka tujuan serta pengertian-pengertiannya dari masyarakat dan pada gilirannya dapat menopang masyarakat yang bersangkutan dengan hasil-hasil penyelidikannya. Jika kesadaran tersebut telah tergugah, maka dimungkinkan untuk mengambil jarak terhadap masyarakat yang ada serta mengembangkan filsafat social yang sebenarnya, yaitu yang memusatkan perhatian pada usaha merombak masyarakat secara manusiawi.

Maka yang menjadi masalah bagi teori kritik adalah menyoroti segala gejala yang menentukan hubungan antara seorang individu dengan masayarakat, mencakup bidang ekonomi, politik, hukum, agama, kesenian, social kemasyarakatan dan ilmu pengetahuan. Selanjutnya diungkapkan bahwa pengalaman hanya dapat terjadi di dalam kerangka suatu

\footnotetext{
${ }^{11}$ Frans Magnes Suseno, Filsafat sebagai, 165.

12 Ibid., 166.
} 
teori kefilsafatan. Namun kerangka ini tidak berada di atas pengalaman, melainkan ikut berkembang berdasarkan penyelidikan empiris. Meskipun teori tidak sama sepenuhnya dengan pengalaman, namun keduanya juga tidak dapat dipisahkan. Keduanya merupakan satu kesatuan dialektik yang mana di dalamnya yang satu berkembang dengan memakai yang lain sebagai sarananya. ${ }^{13}$ Atau dengan kata lain dapat dikatakan telah terjadi hubungan dialektik antara teori kefilsafatan dengan praktis ilmiah positif. Sehingga keduanya harus berjalan beriringan tanpa boleh menghilangkan yang lainnya.

Maka untuk mengetahui teori-teori yang telah dicetuskan oleh Mazhab Frankfurt, menurut Jurgen Habermas, setidaknya ada enam tema utama dalam teori kritis, yaitu: bentuk-bentuk integrasi sosial masyarakat post-liberal, sosialisasi dan pengembangan ego, media massa dan kebudayaan massa, sosiologi social protes, teori seni dan kritik atas positivisme. ${ }^{14}$ Dari keenam tema tersebut telah melahirkan banyak pemikiran-pemikiran termasuk kritik atas perkembangan sosiologi, seni dan kebudayaan masyarakat modern. Namun tema mengenai positivisme merupakan tema yang banyak disinggung dan diperdebatkan. Mengingat positivisme adalah salah satu aliran yang cukup mapan dan memiliki banyak pengikut dan penerus dalam pemikiran filsafat.

Kritik teori sosial kritis atas positivisme merupakan karakteristik sentral seluruh pemikiran aliran tersebut. Kecenderungan positivis dalam ilmu social sejak zaman pencerahan telah memprofokasi teori sosial kritis. Pernyataan Auguste Comte bahwa sosiologi (neo-logisme-nya) harus mencoba menjadi "fisika social", yaitu dengan menjabarkan bagaimana hokum social yang seolah-olah alamiah itu membekukan masa kini. Wacana tanding yang muncul kemudian adalah para ilmuan social kritis mencoba menggambarkan pola-pola historis semacam ini sebagai kapitalisme, rasisme, seksisme, dan dominasi alam. Dalam perkembangannya, dari masa ke masa ilmuan yang melawan proyek positivisme yang menganut sejumlah tesis teori social kritis, khususnya karena pengaruh Mazhab Frankfurt, post modernisme, kajian feminisme dan cultural studies semakin bertambah. ${ }^{15}$

Teori kritis menentang teori tradisional atau positivisme, karena tidak sesuai dengan semangat pencerahan. Sifatnya yang ideologis tidak mungkin menjadi teori yang emansipatoris. Gejala ideologisnya tidak bertujuan untuk mengubah kondisi-kondisi modernitas, tetapi justru melanggengkan status quo. Hal ini justru akan menjadi teori yang menindas dan membelenggu kemandirian masyarakat. Artinya, semangat untuk

${ }^{13}$ Bernard Delfgaauw, Filsafat Abad 20, .....164.

14 F. Budi Hardiman, Menuju Masyarakat Komunikatif: Ilmu Masyarakat, Politik dan PostModernisme Menurut Jurgen Habermas, (Yogyakarta: Kanisius, 1993), xvi.

${ }^{15}$ Fathur Rahman, "Implikasi Teori Sosial Kritis terhadap Perkembangan Riset Psikologi" dalam Jurnal Paradigma, No. 08, th. IV. Juli 2009, 7-8. 
mempertahankan status quo lebih dikedepankan dari pada keinginan untuk membebaskan manusia dari keterkungkungan mitos baru, yaitu rasionalitas instrumentalnya. ${ }^{16}$

Itulah sebabnya, teori kritis melakukan kritik atas keadaan yang demikian dan mencoba melakukan pembebasan manusia dari gejala irrasionalitas masyarakat. Sifat kritis teori ini dipahami selayaknya kritik model Hegelian dan Marxian yang dikembangkan oleh Mazhab Frankfurt melalui istilah "dialektika terbuka"nya. ${ }^{17}$ Dengan mendasarkan pada dialektika terbuka tersebut digunakannya sebagai riset-riset pragmatis Mazhab Frankfurt.

Horkheimer dan Adorno dalam Dialectics of Enlightenment (1972) mengkritik semua teori modernitas terdahulu, termasuk teori Marx atas ketidakperduliannya pada isu yang mereka sebut sebagai "dominasi". Dalam hal ini mereka menyatakan bahwa teori kritis mereka sendiri lebih merupakan kritik menyeluruh atas peradaban dibandingkan dengan karya Mark yang hanya menerapkan kritiknya kepada kapitalisme. Dominasi, menurut Horkheimer dan Adorno, mengacu pada kegemaran masyarakat Barat melihat dunia, termasuk alam sebagai objek yang harus dikuasai bagi kemanfaatan manusia. ${ }^{18}$

Horkheimer dan Adorno tidak melawan pencerahan. Sebagai rasionalitas dari Marxis, mereka berpikir bahwa pencerahan membuka jalan bagi pembebasan. Namun pencerahan abad ke 18 yang membebaskan Eropa dari agama dan mitos, gagal meraih tujuan akhirnya dengan mengabaikan ketidaksempurnaannya dan kecacatannya. Menurut teoritisi Frankfurt, keinginan Yunani terhadap pencerahan cenderung berlebihan dan terlalu mewah; untuk menghapus semua misteri dan mitos dan menggantinya dengan iman dan nalar. Mereka mendukung nalar dan benar-benar ingin menciptakan satu rezim nalar, sehingga dia tidak terlibat dalam dominasi sosial dan intelektual. ${ }^{19}$

Mazhab Frankfurt bertolak dari proyek atau usaha rasio pada abad ke 18 untuk menjadi penyelamat manusia melalui ilmu pengetahuan positif dan penerapannya dalam tehnik. Dikatakan bahwa masa pencerahan terus menerus melanjutkan usahanya untuk membebaskan manusia dari ketakutan dan menjadikannya tuan atas dirinya sendiri. Sasaran Aufklarung adalah membebaskan manusia dari kuasa magis dengan bantuan ilmu

${ }^{16}$ Mazhab Frankfurt tidaklah kolot. Artinya, mereka tidak membela teknologi yang merusak dan tidak mengembalikannya kepada alam primitive dan pra-sejarah. Teoritisi kritis berpikir bahwa alam dapat dikuasai secara manusiawi bagi tujuan manusia. Selain itu orang-orang atau masyarakat yang memiliki perbedaan dapat ditoleransi tanpa harus menghentikan keuntungan kemajuan teknologisnya.

17 F. Budi Hardiman, Kritik Ideologi: Pertautan Pengetahuan dan Kepentingan (Yogyakarta: Kanisius, 1990), 57-8.

${ }^{18}$ Sejak zaman Yunani Kuno, manusia berusaha mengatasi ketakutan mereka dengan menaklukkan berbagai elemen di luar mereka termasuk alam, perempuan, anggota kelompok minoritas dan bahkan dengan masyarakat primitive. Untuk meraih kendali atas lingkungan alam dan social mereka, manhusia tidak hanyna memenuhi kebutuhan mereka, namun juga mengatasi kegelisahan mereka dan menciptakan identitas mereka sendiri.

${ }^{19}$ Ben Agger, Teori Sosial Kritis; Penerapan dan Implikasinya, (Yogayakarta: Kreasi Wacana, 2003), 171-2. 
pengetahuan. ${ }^{20}$ Dengan demikian, dapatlah dipahami bahwa mazhab Frankfurt merumuskan sasarannya sebagai teori kritis dengan bertolak pada Aufklarung.

Aufklarung dalam pandangan Adorno merupakan arti yang paling utama dari pemikiran progressif, yang bertujuan untuk emansipasi manusia dari ketakutan dan membangun kemerdekaan dirinya. Pencerahan adalah projek menyingkirkan mitos-mitos dari logos (akal budi) dan beralih pada tradisi berpikir kritis yang disebut rasio kritis. Adorno menyatakan bahwa manusia telah terjebak dalam dialektika; manusia sebagai subjek yang menguasai alam akhirnya menjadi penguasaan objek itu sendiri. manusia ingin membebaskan dirinya pada realitasnya justru diperbudak alam. ${ }^{21}$ Di sinilah terjadi suatu pembalikan (umschliag); manusia yang telah menyatakan diri sebagai subjek justru menjadi objek dari alam itu sendiri. Di sinilah lenyapnya kebebasan manusia yang disebut sebagai "Negativitas Total". 22

Aufklarung sendiri timbul sebagai upaya manusia agar akal budi manusia kembali berperan untuk memikirkan dan mengendalikan pribadi manusia dan tidak lagi sematamata diikat oleh dogma-dogma agama, seperti pada abad pertengahan dan zaman kegelapan. Bila akal budi dapat berkembang demikian, maka manusia akan memiliki kebebasan. Di samping itu ciri alam pikir pada zaman Aufklarung adalah memandang semua manusia sama. Oleh karena itu alam pikir tidak dapat menerima pendangan tentang status atau kekuasaan yang terbawa oleh keturunan. ${ }^{23}$

Mazhab Frankfurt ingin mengkritik rasio-tehnik industrial dalam masyarakat pasca industri. Sebab menurut mereka rasio seperti itu sudah tidak sesuai dengan tuntutan serta tujuan rasio yang sebenarnya. Mereka ingin membantu teori yang mengkritik struktur dan konfigurasi masyarakat actual sebagai akibat dari suatu pemahaman yang keliru tentang rasio. Hal ini tentu saja mengandaikan bahwa mereka mempunyai suatu ide tentang suatu rasio yang lebih orisinil dan fundamental, sebagai titik acuan untuk merumuskan kelemahan-kelemahan masyarakat industri dan berbagai macam gejala yang terdapat dalam seluruh tatanan social. Mereka menjelaskan semua itu dengan bertolak pada pemahaman tentang rasio dewasa ini, yaitu: rasio tehnik instrumental. ${ }^{24}$

Di dalam Mazhab Frankfurt banyak ilmu pengetahuan yang diusahakan secara berhubungan. Hal yang demikian ini telah memainkan peranan yang cukup besar dalam

${ }^{20}$ Rasio, sebagaimana dipahami dan diagung-agungkan oleh massa Aufklarung bertujuan untuk membebaskan manusia dari cengkeraman alam dan membangun suatu tatanan politik social yang dapat melaksanakan cita-cita kebebasan dan keadilan. Mazhab Frankfurt bermaksud memperjelas secara rasional struktur yang dimiliki oleh masyarakat industry sekarang dan melihat akibat-akibat struktur tersebut dalam kehidupan manusia dan dalam kebudayaannya.

${ }^{21}$ Adorno, T.W., Negative Dialectics, (London: Routledge and Kegan Paul, 1973).

${ }^{22}$ Sunarto, "Negativitas Total; Kritik Adorno terhadap Rasionalitas dan Seni Masyarakat Modern", dalam Pelataran Seni, Volume I Nomor 2, September 2016., 140.

${ }^{23}$ Imam Barnadib, Dasar-Dasar Kependidikan, (Jakarta: Ghalia Indonesia, 1996), 23.

${ }^{24}$ Sunarto, "Konstruksi Epistemologi Max Horkheimer: Kritik atas Masyarakat Modern" dalam Listiyono Santoso dan Sunarto dkk., Epistemologi Kiri... 96. 
buku Dialek Der Aufklarung (1947). Kitab ini memuat dasar-dasar penyelidikan mengenai arti serta peranan penguasa di dalam masayarakat. Negara, Gereja, Universitas dan perusahaan semuanya merupakan tiang-tiang penyangga sebuah sistem tanpa nama. Kelembagaan yang sudah mapan acap kali tanpa secara tegas disadari oleh para pendukung lembaga-lembaga tersebut.

Sistem ini melakukan pengendalian dengan I'tikad tidak memungkinkan terjadinya perubahan-perubahan di dalamnya. Karenaya merupakan suatu tatanan bagi teori kritik untuk menyingkapkan bentuk-bentuk pengendalian yang bersifat tersembunyi. Seperti tentang keluarga, moral seksual, pendidikan, paksaan untuk berprestasi di bidang social dan ekonomi. Sebagai pengganti oteoriter, maka harus dibangun suatu masyarakat yang anti otoriter. ${ }^{25}$ Oleh karena itu struktur masyarakat haruslah dirubah dan diusahakan suatu pendidikan yang anti orotiter. Kemudian masyarakat yang anti otoriter hanya dapat diwujudkan dan dapat berfungsi manakala batin manusianya tidaklah otoriter pula.

\section{Penutup}

Masyarakat modern telah terkontaminasi oleh gerakan pencerahan (Aufklarung) abad ke 18 dengan konsep pengagungan rasionya. Berbasis pada rasio inilah, Mazhab Frankfurt mulai menganalisis keadaaan masyarakat pasca industri dan mengkritiknya, karena tidak sesuai dengan konsep rasionalitas pencerahan itu sendiri. Akhirnya dengan senjata teori kritisnya ia membongkar kedok ideologis teori irrasionalitas masyarakat, termasuk juga kritik terhadap paham bebas nilai dan ilmu-ilmu, tak terkecuali filsafat.

Teori kritis tidak memisahkan teori dari praktik, pengetahuan dari tindakan, rasio teoris dari rasio praktis. Perlu dicatat bahwa rasio praktis tidak boleh dicampuradukkan dengan rasio instrumental yang hanya memperhitungkan alat atau sarana saja. Mazhab Frankfurt menunjukkan bahwa teori atau ilmu yang bebas-nilai adalah hal yang mustahil, palsu. Karena itu teori kritis selalu mengedepankan transformasi praktis masyarakat. Dengan harapan dapat memberikan pencerahan sekaligus progressifitas yang berarti bagi kemajuan sejati dan bukan kemajuan semu.

Mazhab Frankfurt sebagai aliran filsafat Neo-Marxis berusaha dan mencoba membebaskan manusia dari segala belenggu manipulasi pengisapan dan penindasan teknokrat modern. Sebagai rasionalis dan marxis, mereka berpikir bahwa pencerahan (Aufklarung) dapat membuka jalan bagi seluruh pembebasan. Masalah sebenarnya menurut mereka adalah usaha filsafat dan budaya Barat untuk mendominasi objek alam dan orang lain. Namun mereka juga sangat profetis dan penuh harap membayangkan suatu masyarakat praksis, kerja dan pemain kreatif di mana alam "diselamatkan" dan "dibebaskan".

\footnotetext{
${ }^{25}$ Bernard Delfgaauw, Filsafat Abad 20, ....166.
} 


\section{Daftar Pustaka}

Adorno, T.W., Negative Dialectics, (London: Routledge and Kegan Paul, 1973).

Akhyar Yusuf Lubis, Pemikiran Kritis Kontemporer; dari Teori Kritis, Culture Studies, Feminism, Post-Kolonial hingga Multikulturalisme, (Jakarta: Rajawali Press, 2016).

Agger, Ben, Teori Sosial Kritis; Penerapan dan Implikasinya, (Yogayakarta: Kreasi Wacana, 2003).

Delfgaauw, Bernard, Filsafat Abad 20 (Yogyakarta: Tiara Wacana, 1988).

Kellner, Douglas, "Frankfurt School (Aliran Frankfurt)", dalam Adam Kuper dan Jessica Kuper (ed.), Ensiklopedi Ilmu-ilmu Sosial, terj. Haris Munandar (et.al), (Jakarta: Raja Grafindo Persada, 2000).

F. Budi Hardiman, Kritik Ideologi: Pertautan Pengetahuan dan Kepentingan (Yogyakarta: Kanisius, 1990).

F. Budi Hardiman, Menuju Masyarakat Komunikatif: Ilmu Masyarakat, Politik dan PostModernisme Menurut Jurgen Habermas, (Yogyakarta: Kanisius, 1993).

Fathur Rahman, "Implikasi Teori Sosial Kritis terhadap Perkembangan Riset Psikologi" dalam Jurnal Paradigma, No. 08, th. IV. Juli 2009.

Frans Magnes Suseno, Filsafat Sebagai Ilmu Kritis, (Yogyakarta: Kanisius, 1992).

Friedman, George, The Political Philosophy of Frankfurt School (London: Cornel Univercity Press, 1981).

Imam Barnadib, Dasar-Dasar Kependidikan, (Jakarta: Ghalia Indonesia, 1996).

K. Bertens, Filsafat Barat abad XX: Ingris-Jerman, (Jakarta: Gramedia, 1983).

Sunarto, "Konstruksi Epistemologi Max Horkheimer: Kritik atas Masyarakat Modern"dalam Listiyono, Santoso dan Sunarto dkk., Epistemologi Kiri, (Yogyakarta: Ar-Ruz, 2003).

Sunarto, "Negativitas Total; Kritik Adorno terhadap Rasionalitas dan Seni Masyarakat Modern”, dalam Pelataran Seni, Volume I Nomor 2, September 2016. 